Article

\title{
Roughage to Concentrate Ratio and Saccharomyces cerevisiae Inclusion Could Modulate Feed Digestion and In Vitro Ruminal Fermentation
}

\author{
Kampanat Phesatcha ${ }^{1}\left(\mathbb{D}\right.$, Burarat Phesatcha $^{2}$, Metha Wanapat ${ }^{3}\left(\mathbb{D}\right.$ and Anusorn Cherdthong ${ }^{3, *(1)}$ \\ 1 Department of Animal Science, Faculty of Agriculture and Technology, Nakhon Phanom University, \\ Nakhon Phanom 48000, Thailand; kampanatmon@gmail.com \\ 2 Department of Agricultural Technology and Environment, Faculty of Sciences and Liberal Arts, \\ Rajamangala University of Technology Isan, Nakhon Ratchasima 30000, Thailand; \\ Burarat_kat@hotmail.co.th \\ 3 Tropical Feed Resources Research and Development Center (TROFREC)Department of Animal Science, \\ Faculty of Agriculture, Khon Kaen University, Khon Kaen 40002, Thailand; metha@kku.ac.th \\ * Correspondence: anusornc@kku.ac.th; Tel.: +66-4320-2362
}

Received: 25 August 2020; Accepted: 1 October 2020; Published: 9 October 2020

\begin{abstract}
The objective of this research was to investigate the effect of the roughage-to-concentrate $(\mathrm{R}: \mathrm{C})$ ratio and the addition of live yeast $(\mathrm{LY})$ on ruminal fermentation characteristics and methane $\left(\mathrm{CH}_{4}\right)$ production. The experimental design was randomly allocated according to a completely randomized design in a $4 \times 4$ factorial arrangement. The first factor was four rations of R:C at 80:20, 60:40, 40:60, and 20:80, and the second factor was an additional four doses of Saccharomyces cerevisiae (live yeast; LY) at $0,2.0 \times 10^{6}, 4.0 \times 10^{6}$, and $6.0 \times 10^{6}$ colony-forming unit (cfu), respectively. For the in vitro method, during the incubation, the gas production was noted at $0,1,2,4,6,8,10$, $12,18,24,48,72$, and $96 \mathrm{~h}$. The rumen solution mixture was collected at $0,4,8,12$, and $24 \mathrm{~h}$ of incubating after inoculation. Cumulative gas production at $96 \mathrm{~h}$ was highest in the R:C ratio, at 20:80, while the addition of LY improves the kinetics and accumulation of gas $(p>0.05)$. Maximum in vitro dry matter digestibility (IVDMD) and in vitro organic matter digestibility (IVOMD) at $24 \mathrm{~h}$ after incubation were achieved at the R:C ratio 20:80 and the addition of LY at $6 \times 10^{6} \mathrm{cfu}$, which were greater than the control by $13.7 \%$ and $12.4 \%$, respectively. Ruminal $\mathrm{pH}$ at $8 \mathrm{~h}$ after incubation decreased with an increased proportion of concentrates in the diet, whereas it was lowest when the $\mathrm{R}: \mathrm{C}$ ratio was at 20:80. Increasing the proportion of a concentrate diet increased total volatile fatty acid (TVFA) and propionic acid (C3), whereas the acetic acid (C2) and C2-to-C3 ratios decreased $(p<0.05)$. TVFA and C 3 increased with the addition of LY at $6 \times 10^{6} \mathrm{cfu}$, which was greater than the control by $11.5 \%$ and $17.2 \%$, respectively. No interaction effect was observed between the R:C ratio and LY on the $\mathrm{CH}_{4}$ concentration. The calculated ruminal $\mathrm{CH}_{4}$ production decreased with the increasing proportion of concentrates in the diet, particularly the $\mathrm{R}: \mathrm{C}$ ratio at 20:80. The $\mathrm{CH}_{4}$ production for $\mathrm{LY}$ addition at $6 \times 10^{6} \mathrm{cfu}$ was lower than the control treatment by $17.2 \%$. Moreover, the greatest populations of bacteria, protozoa, and fungi at $8 \mathrm{~h}$ after incubation were found with the addition of LY at $6 \times 10^{6} \mathrm{cfu}$, which were higher than the control by $19.0 \%, 20.7 \%$, and $40.4 \%$, respectively. In conclusion, a high ratio of roughage and the concentrate and addition of $\mathrm{LY}$ at $6.0 \times 10^{6} \mathrm{cfu}$ of the total dietary substrate could improve rumen fermentation, improve feed digestibility, and reduce the $\mathrm{CH}_{4}$ production.
\end{abstract}

Keywords: direct fed microbial; diet ratio; digestibility; ruminal fermentation; live yeast 


\section{Introduction}

In recent years, with increased consumer concern for health, quality animal products, and environmental effects, the European Union has prohibited antibiotics and synthetic chemicals as feed additives. Supplementation of direct fed microbial has been shown to improve animal performance due to its ability to modify feed utilization and the efficiency [1,2]. Live yeast (LY) is one of the most studied of those direct-fed microbes; specifically, Saccharomyces cerevisiae is used not only to improve production performance, but also to reduce the risk of transferring antibiotic resistance or possible human pathogens and to minimize the excretion of pollutants [3-5]. S. cerevisiae has been used for many years, to promote ruminal fermentation, minimize the loss of energy and nutrients, and thus increase the ruminant production system. Some researchers have found that supplementation of the $S$. cerevisiae enhances ruminant digestion of feed in a variety of ways, such as increasing nutrient digestibility [6], maximizing the ruminal volatile fatty acid (VFA) proportion, decreasing ammonia nitrogen $\left(\mathrm{NH}_{3}-\mathrm{N}\right)$ [7], alleviating $\mathrm{pH}$ fluctuation, and stimulating the population of ruminal microorganisms [8]. High portions of concentrate in the ration significantly decreased the ruminal $\mathrm{pH}$ and $\mathrm{NH}_{3}-\mathrm{N}$ concentration. The addition of yeast resulted in a numerical increased in the ruminal $\mathrm{pH}$ and concentration of VFA [9]. Kumprechtova et al. [10] mentioned that the daily inclusion of high-producing dairy cows with LY significantly increased milk production than the control group $3.6 \%$ (38.95 vs. $37.38 \mathrm{~kg} /$ day, respectively), without reducing the percentage of milk fat and protein. In early lactation, LY supplementation favorably affected the metabolic status and may have exerted a protective effect on the liver in high production. In addition, ruminal methanogenesis is a major metabolic pathway in the elimination of hydrogen. Enteric methane $\left(\mathrm{CH}_{4}\right)$ is a waste of energy for the ruminant and a major source of greenhouse gas from livestock. The practical methods of minimizing its production are thus actively researched. LY has the potential to change the fermentation process in the rumen that reduces the formation of $\mathrm{CH}_{4}$ gas [9]. Chaucheyras et al. [11] reported a shift in $\mathrm{H}_{2}$ utilization from methanogenesis to reductive acetogenesis by yeast. $S$. cerevisiae strains have been selected for the specific reduction of ruminal $\mathrm{CH}_{4}$ production [11], whereas other strains may indirectly decrease $\mathrm{CH}_{4}$ production by improving ruminal fiber degradation and feed conversion efficiency [7]. An increased proportion of starch in the diet changes concentrations of ruminal VFAs so that less acetate and more propionate formed and there is limited supply of hydrogen for methanogenesis. As the proportion of propionic acid increases, the $\mathrm{pH}$ also decreases, which reduces methanogenic activity [12]. It was proposed that additions of $\mathrm{LY}$ with different roughage-to-concentrate (R:C) ratios, using treated rice straw with $2.0 \%$ urea $+2.0 \%$ lime $\left(\left(\mathrm{Ca}(\mathrm{OH})_{2}\right)\right.$ (ULTRS) as basal roughage, can improve rumen fermentation efficiency and reduce $\mathrm{CH}_{4}$ production. Therefore, the objective of the current study was to investigate the effect of the of LY addition and the R:C ratio, using ULTRS as basal roughage, on ruminal $\mathrm{pH}$, ruminal fermentation, microbial population, and methane emission in in vitro gas production.

\section{Materials and Methods}

The study design and plan strictly followed the norms of the Animal Ethics Committee of Nakhon Phanom University (permission No. AENPU A2/2560). This study primarily involved laboratory analysis of ruminant feeds, for which requisite permission was granted to collect the rumen fluid from animals based on the Thailand Ethics of Animal Experimentation of National Research Council.

\subsection{Experimental Design and Dietary Treatments}

The experimental design was randomly allocated according to a completely randomized design $(C R D)$ in a $4 \times 4$ factorial arrangement, with three replicates per treatment, including blank triplicates (medium only). Incubations were repeated on three separate days (runs). The first factor was four rations of $R: C$ at 80:20, 60:40, 40:60, and 20:80, and the second factor was an additional four doses of S. cerevisiae (live yeast; LY), at $0,2.0 \times 10^{6}, 4.0 \times 10^{6}$, and $6.0 \times 10^{6}$ colony-forming unit (cfu), 
respectively. The rice straw (Oryza sativa L.) (RS) was treated with $2.0 \%$ urea $+2.0 \%$ lime (ULTRS) (Thai Poly Chemicals Co., Ltd., Samut Sakhon, Thailand) by adding $2 \mathrm{~g}$ urea and $2 \mathrm{~g}$ lime in $100 \mathrm{~mL}$ of water to $100 \mathrm{~g}(91 \% \mathrm{DM})$ of RS as a roughage source. The amount of a urea-lime solution was sprayed onto a stack of whole straw bales, and then the stack was covered with a plastic sheet at least 10 days. As demonstrated in Table 1, the concentrate was formulated with ingredients. ULTRS and the concentrate diet were dried at $60{ }^{\circ} \mathrm{C}$ and passed through a screen $(1 \mathrm{~mm})$, to determine the chemical analysis of dry matter (DM), organic matter (OM), and crude protein $(\mathrm{CP})$ by using standard methods [13]. The fiber content, especially neutral detergent fiber (NDF) and acid detergent fiber (ADF), was determined according to Van Soest et al. [14]. The yeast strain S. cerevisiae in this study was obtained from the That Phanom district, Nakhon Phanom Province, Thailand, as well as cultured and amplified by using a malt extract medium containing a $0.1 \mathrm{~g}$ chloramphenicol/L and $130 \mathrm{~g}$ malt extract. Then, the total viable yeast numbers were counted by using the spread plate method in the form of cfu according to Wang et al. [7]. The yeasts were then stored at $4{ }^{\circ} \mathrm{C}$ before the start of in vitro fermentation.

Table 1. Ingredients and chemical composition of concentrate and $2 \%$ urea plus $2 \%$ calcium hydroxide $\left(\mathrm{Ca}(\mathrm{OH})_{2}\right)$ treated rice straw (ULTRS) used in the experiment.

\begin{tabular}{|c|c|c|c|c|c|c|}
\hline \multirow{2}{*}{ Item } & \multirow{2}{*}{ Concentrate } & \multirow{2}{*}{ ULTRS } & \multicolumn{4}{|c|}{ Roughage: Concentrate Ratio } \\
\hline & & & $80: 20$ & $60: 40$ & $40: 60$ & $20: 80$ \\
\hline \multicolumn{7}{|l|}{ Ingredient (kg of DM) } \\
\hline Cassava chip & 65.0 & & & & & \\
\hline Rice bran & 10.5 & & & & & \\
\hline Coconut meal & 11.0 & & & & & \\
\hline Palm kernel meal & 6.0 & & & & & \\
\hline Urea & 3.0 & & & & & \\
\hline Molasses & 2.0 & & & & & \\
\hline Mineral premix & 1.0 & & & & & \\
\hline Salt & 1.0 & & & & & \\
\hline Sulfur & 0.5 & & & & & \\
\hline \multicolumn{7}{|l|}{ Chemical composition } \\
\hline Dry matter (DM), \% & 87.8 & 50.6 & 86.4 & 85.6 & 85.1 & 84.7 \\
\hline \multicolumn{7}{|c|}{$\%$ Dry matter } \\
\hline Organic matter (OM) & 93.7 & 90.1 & 92.9 & 92.2 & 91.6 & 91.0 \\
\hline Crude protein $(\mathrm{CP})$ & 14.1 & 5.8 & 12.5 & 10.9 & 9.2 & 7.6 \\
\hline Neutral detergent fiber (NDF) & 18.9 & 71.4 & 29.6 & 40.1 & 49.7 & 60.3 \\
\hline Acid detergent fiber (ADF) & 14.8 & 56.3 & 23.1 & 31.3 & 39.9 & 47.8 \\
\hline Total digestible nutrients (TDN) ${ }^{1}$ & 78.9 & - & - & - & - & - \\
\hline
\end{tabular}

\subsection{Rumen and Substrate Inocula}

The rumen fluid was collected from two Thai native beef cattle with an initial body weight of $200 \pm 15 \mathrm{~kg}$. Thai native beef cattle were also adapted to concentrate diet $(14.1 \% \mathrm{CP}$ and $78.8 \%$ total digestive nutrient, dry-matter basis) (at $0.5 \%$ of live weight), and RS treated with urea and lime was fed ad libitum. Two cattle are the same as mentioned before, were housed in separate pens, and received vitamin/mineral blocks and fresh water for 14 days consistently. On day 15, before morning feeding, $1000 \mathrm{~mL}$ of rumen fluid was obtained from each beef cattle, using a suction pump, and then pooled and strained into an Erlenmeyer flask from four layers of cheesecloth. An experimental feed sample was weighed into $50 \mathrm{~mL}$ bottles of each total mixed substrate $(200 \mathrm{mg})$. Bottles with the mixtures of substrate treatment were received $\mathrm{CO}_{2}$ flushing and pre-warmed in a water bath at $39{ }^{\circ} \mathrm{C}$ for $96 \mathrm{~h}$. Bottles were sealed with a rubber and aluminum cap and then incubated at $39^{\circ} \mathrm{C}$ for $96 \mathrm{~h}$. Ruminal fluid was 
combined with the artificial saliva solution in a proportion of $2: 1(\mathrm{~mL} / \mathrm{mL})$, at $39^{\circ} \mathrm{C}$, under continuous $\mathrm{CO}_{2}$ flushing, according to Makkar et al. [16]. A portion of the rumen-fluid medium (40 mL) was transferred into each bottle, and blanks with only rumen fluid were used; after that, the LY was added, respectively, and then incubated at $39^{\circ} \mathrm{C}$, in a water bath, as Blummen and Orskov [17] described.

\subsection{In Vitro Gas Production and Fermentation Characteristics}

The production of gas was measured immediately following incubation and after at $0,1,2$, $4,6,8,12,24,48,72$, and $96 \mathrm{~h}$, as well as using a calibrated syringe and a pressure transducer. Cumulative-production-of-gas data were fitted to the model of Ørskov and McDonald [18], as follows:

$$
y=a+b\left(1-e^{-c t}\right)
$$

where $\mathrm{a}=$ the gas production from the immediately soluble fraction, $\mathrm{b}=$ the gas production from the insoluble fraction, $c=$ the gas production rate constant for the insoluble fraction $(b), t=$ incubation time, $(\mathrm{a}+\mathrm{b})=$ the potential extent of gas production, and $\mathrm{y}=$ gas produced at time " $\mathrm{t}$ ".

Fermented liquid was collected at 4 and $8 \mathrm{~h}$ post-incubation, to measure the $\mathrm{pH}$, and then filtered through four layers of cheesecloth. Twenty-five milliliters of rumen fluid was separated into two portions; for a total direct count of bacteria, protozoa, and fungi, the first portion was fixed with a $10 \%$ formalin solution in a sterilized $0.9 \%$ saline solution. The populations of bacteria, protozoa, and fungi were illustrated by a haemacytometer [19]. The second portion was for $\mathrm{NH}_{3}-\mathrm{N}$ analysis and total volatile fatty acid (TVFA) using $2 \mathrm{~mL}$ of sulphuric acid $\left(\mathrm{H}_{2} \mathrm{SO}_{4}\right)$ added to $18 \mathrm{~mL}$ of incubation medium centrifuged at $16,000 \times g$ for $15 \mathrm{~min}$, and the supernatant was stored at $-20{ }^{\circ} \mathrm{C}$ before $\mathrm{NH}_{3}-\mathrm{N}_{\text {analysis }}$ (Kjeltech Auto 1030 Analyzer, Tecator, Sweden). VFA profiles (acetic acid (C2), propionic acid (C3), and butyric acid (C4)) were analyzed, using high-performance liquid chromatography (instruments by controller water model 600E, water model 484 UV detector, column Nova-Pak C18, column size $3.9 \mathrm{~mm} \times 300 \mathrm{~mm}$, mobile phase $10 \mathrm{mM} \mathrm{H}_{2} \mathrm{PO}_{4}(\mathrm{pH} \mathrm{2.5)})$, and the production of methane $\left(\mathrm{CH}_{4}\right)$ was estimated by using the Moss et al. [20] method as follows: $\mathrm{CH}_{4}$ production $=0.45$ (acetic acid) -0.275 (propionic acid) +0.4 (butyric acid). Equation indicates that the molar percentage of volatile fatty acids (VFAs) influences the production of methane in the rumen. Acetate and butyrate promote methane production, while propionate formation can be considered as a competitive pathway for hydrogen use in the rumen. The inocula after inoculation were filtered through pre-weighed Gooch crucibles, and residual dry matter was estimated. The percent loss in weight was determined and presented as in vitro dry matter degradability (IVDMD). The dried feed sample and residue left above was ashed at $550{ }^{\circ} \mathrm{C}$, for determination of in vitro organic matter degradability (IVOMD), according to Tilley and Terry [21].

\subsection{Statistical Analysis}

All of the experimental data were analyzed as a $4 \times 4$ factorial arrangement, in a completely randomized design (CRD), and subjected to the general linear model (GLM) of SAS version 9.0 (SAS Inst. Inc., Cary, NC, USA) [22]. The statistical, model including R:C ratio, dose of S. cerevisiae, and interaction effects, was as follows: $Y i j=\mu+A i+B j+A B i j+\varepsilon i j$, where Yijk is an observation, $\mu$ is the overall mean, $A$ is $R: C$ ratio effect $(i=1,2,3,4), B$ is dose of $S$. cerevisiae effect $(j=1,2,3,4)$, AB is the interaction effect of R:C ratio and dose of $S$. cerevisiae, and $\varepsilon$ ij the residual effect. For all para meters, differences among treatments means were contrasted by Tukey's multiple comparison test when $p<0.05$ [23].

\section{Results and Discussions}

\subsection{Chemical Composition of Experimental Feeds}

Table 1 shows the chemical composition of experimental feeds. The mixture of concentrate was formulated by using soybean meal, cassava chip, and available local byproducts. The nutritive value 
of the concentrate was $87.8,93.7,14.1,18.9$, and $14.8 \%$ for DM, OM, CP, NDF, and ADF, respectively. RS is a byproduct of agriculture, which is abundant in the tropic, and can be used to feed ruminants, especially during the dry season because it lacks quality roughage. RS has low nutritional value, high fiber and lignin, low voluntary intake of feed, low digestibility, and low crude protein content, thus increasing the nutritive value of RS with urea, and straw treated with calcium hydroxide can be used to increase the production of ruminants [24]. Straw treatment with calcium hydroxide, along with a low urea level, was of particular interest. The price of calcium hydroxide $\left(\mathrm{Ca}(\mathrm{OH})_{2}\right)$ or lime, an alkaline, is cheaper than urea, and it can provide enough nitrogen for microorganisms in the rumen. RS treated with $2 \%$ urea $+2 \% \mathrm{Ca}(\mathrm{OH})_{2}$ in this study contains $5.8 \% \mathrm{CP}, 71.4 \% \mathrm{NDF}$, and $51.3 \%$ ADF, similar to Polyorach et al. [25], who which reported that RS treated with urea and calcium hydroxide increased crude protein content, DM intake, the digestibility of nutrients and ruminal VFA concentration. There is potential for using urea calcium hydroxide treatments to enrich the nutritive value of RS.

\subsection{In Vitro Gas Production Kinetics}

There was no interaction effect between R:C ratios and LY on the kinetics of gas $(p>0.05)$ (Table 2). Gas production kinetics, including gas production from the immediately soluble fraction (a), the insoluble fraction (b), the gas production rate constant for the insoluble fraction (c), and the potential extent of gas production $(a+b)$ and accumulated gas production $(96 \mathrm{~h})$, were affected by the $\mathrm{R}: \mathrm{C}$ ratio and $\mathrm{LY}$ addition $(p<0.05)$. Cumulative gas production at $96 \mathrm{~h}$ was highest in the $\mathrm{R}: \mathrm{C}$ ratio, at 20:80. The inclusion of a high-concentrate proportion results in increases in the fermentation rate and extent [26]. Similarly, Kang et al. [27] found that cumulative gas production increased with the increasing proportion of concentrates in the diet. Moreover, the addition of LY improves the gas kinetics and accumulation of gas, and this could be due to the fact that LY might stimulate the rumen microbe and greater digestibility of the incubated substrate, thus resulting in improved gas production kinetics. Tang et al. [28] revealed that supplementation of a yeast culture increased the cumulative gas production. These results are in agreement with Wang et al. [7], who reported that supplementation of a yeast culture increased the total gas production when incubating different diet types. The inclusion of yeast may not only increase total gas production but also cause qualitative changes in the gases produced by increasing animals and rumen efficiency so as to contribute less negative environmental effects [29].

\subsection{In Vitro Digestibility}

The effect of the $\mathrm{R}: \mathrm{C}$ ratio and $\mathrm{LY}$ addition on ruminal $\mathrm{pH}, \mathrm{NH}_{3}-\mathrm{N}$, and in vitro digestibility are shown in Table 3. There was no significant interaction effect between the R:C ratio and LY addition on in vitro digestibility. With an increasing concentrate proportion, the in vitro dry matter digestibility (IVDMD) and in vitro organic matter digestibility (IVOMD) increased $(p<0.05)$. These findings agreed with Kang et al. [27], in regard to improving in vitro digestibility by increasing the proportion of concentrates in the diet. This could be due to the resulting induction in microbial growth, which improved digestibility afterward. The degradability of IVDMD and IVOMD had also increased with the addition of the LY dose. Maximum IVDMD and IVOMD, at $24 \mathrm{~h}$ after incubation, were achieved at the R:C ratio 20:80 and the addition of LY at $6 \times 10^{6} \mathrm{cfu}$, which were greater than the control by $13.7 \%$ and $12.4 \%$, respectively. Similarly, Wang et al. [7] found that the addition of LY improved IVDMD and in vitro NDF disappearance (IVNDFD). Williams et al. [6] indicated that the inclusion of S. cerevisiae increased dry-matter digestibility when hay was fed to steers. Tang et al. [28] reported that the addition of $S$. cerevisiae with low-quality roughage enhanced in vitro digestibility. Moreover, the addition of $S$. cerevisiae at $2.5 \mathrm{~g} / \mathrm{d}$ increased NDF and the digestibility of either extract in cattle [30]. Similarly, Cagle et al. [12] also observed that the addition of dry LY at $10 \mathrm{~g} / \mathrm{d}$ in growing and finishing beef cattle increased DM and NDF digestibility. The fact that the digestibility of nutrients improved with the addition of $S$. cerevisiae could be due to the stimulation of the rumen microbe to a higher 
rate of feed digestion. Furthermore, it has been suggested that $S$. cerevisiae can scavenge the available oxygen on the surfaces of freshly ingested feeds to maintain metabolic activity, thereby reducing the potential for redox in the rumen [11,31,32].

Table 2. The effect of roughage-to-concentrate (R:C) ratio with live yeast (LY) supplementation on gas kinetics and cumulative gas production.

\begin{tabular}{|c|c|c|c|c|c|c|c|}
\hline \multirow{2}{*}{ Treatment } & \multirow{2}{*}{$\mathrm{R}: \mathrm{C}^{1}$} & \multirow{2}{*}{$\mathrm{LY}^{2}$} & \multicolumn{4}{|c|}{ Gas Kenetics ${ }^{3}$} & \multirow{2}{*}{$\begin{array}{c}\text { Gas }(96 \mathrm{~h}) \\
\mathrm{mL} / 0.2 \mathrm{~g} \mathrm{DM} \\
\text { Substrate }\end{array}$} \\
\hline & & & a & $\mathbf{b}$ & c & $a+b$ & \\
\hline 1 & \multirow[t]{4}{*}{$80: 20$} & 0 & -3.1 & 76.4 & 0.03 & 73.3 & 65.4 \\
\hline 2 & & 2 & -2.7 & 74.3 & 0.03 & 66.1 & 64.3 \\
\hline 3 & & 4 & -0.8 & 71.5 & 0.03 & 70.7 & 66.7 \\
\hline 4 & & 6 & -2.2 & 73.4 & 0.03 & 71.7 & 66.1 \\
\hline 5 & \multirow[t]{4}{*}{$60: 40$} & 0 & -0.4 & 70.7 & 0.04 & 70.3 & 68.8 \\
\hline 6 & & 2 & 1.3 & 69.2 & 0.04 & 71.5 & 70.2 \\
\hline 7 & & 4 & 1.1 & 69.8 & 0.04 & 70.9 & 71.1 \\
\hline 8 & & 6 & 1.6 & 69.1 & 0.04 & 70.7 & 69.7 \\
\hline 9 & \multirow[t]{4}{*}{$40: 60$} & 0 & 1.1 & 70.8 & 0.05 & 69.7 & 67.1 \\
\hline 10 & & 2 & 1.7 & 70.1 & 0.05 & 68.4 & 68.3 \\
\hline 11 & & 4 & 2.8 & 69.2 & 0.05 & 66.4 & 70.6 \\
\hline 12 & & 6 & 1.3 & 68.8 & 0.05 & 67.5 & 68.4 \\
\hline 13 & \multirow[t]{4}{*}{$20: 80$} & 0 & 3.1 & 68.0 & 0.07 & 71.1 & 72.0 \\
\hline 14 & & 2 & 3.4 & 71.9 & 0.07 & 75.3 & 75.2 \\
\hline 15 & & 4 & 4.0 & 74.2 & 0.07 & 78.2 & 79.1 \\
\hline \multirow[t]{2}{*}{16} & & 6 & 4.3 & 73.1 & 0.07 & 77.4 & 79.4 \\
\hline & SEM & & 0.38 & 0.43 & 0.02 & 0.35 & 0.39 \\
\hline \multicolumn{8}{|c|}{ Comparison } \\
\hline \multicolumn{3}{|c|}{$\mathrm{R}: \mathrm{C}$} & 0.03 & 0.02 & 0.03 & 0.04 & 0.04 \\
\hline \multicolumn{3}{|c|}{ LY } & 0.02 & 0.0 .01 & 0.02 & 0.04 & 0.03 \\
\hline \multicolumn{3}{|c|}{ Interaction } & 0.61 & 0.49 & 0.55 & 0.19 & 0.11 \\
\hline
\end{tabular}

${ }^{1} \mathrm{R}: \mathrm{C}$, roughage-to-concentrate ratio; ${ }^{2} \mathrm{LY}$, live yeast addition $\left(\times 10^{6}\right.$ colony-forming unit); ${ }^{3}$ Gas kinetic, a, the gas production from the immediately soluble fraction; $b$, the gas production from the insoluble fraction; $c$, the gas production rate constant for the insoluble fraction (b); $a+b$, the gas potential extent of gas production; SEM, standard error of the mean.

\subsection{Ruminal $\mathrm{pH}$ and Ammonia-Nitrogen $\left(\mathrm{NH}_{3}-\mathrm{N}\right)$ Concentration}

The effect of the $\mathrm{R}: \mathrm{C}$ ratio and $\mathrm{LY}$ addition on ruminal $\mathrm{pH}$ and the $\mathrm{NH}_{3}-\mathrm{N}$ concentration is shown in Table 4. There were no interactions between the R:C ratio and LY addition on ruminal $\mathrm{pH}$ and the $\mathrm{NH}_{3}-\mathrm{N}$ concentration in the present study. The $\mathrm{pH}$ value ranged from 6.2 to 6.9 for all treatments. However, the result showed that ruminal $\mathrm{pH}$ at $8 \mathrm{~h}$ after incubation decreased with an increased proportion of concentrates in the diet, whereas it was lowest when the R:C ratio was at 20:80. Similarly, Cherdthong et al. [33] revealed that the diets containing a high proportion of concentrate usually caused a marked reduction in ruminal $\mathrm{pH}$, inhibited the digestion rate, and reduced the activity of cellulolytic bacteria. Ruminal $\mathrm{pH}$ is a major index representing the rumen environment's internal homeostasis; hence, maintaining a consistently stable ruminal $\mathrm{pH}$ is essential to ensure optimal rumen ecology, rumen fermentation, and microbial growth. Ruminants typically have a highly developed system for maintaining a ruminal $\mathrm{pH}$ range of 6.0-7.0 [34]. Similarly, the present result demonstrated that, even though $\mathrm{pH}$ after $8 \mathrm{~h}$ incubation reduced, it maintained in the normal range for microbial activity. In general, $\mathrm{pH}$ stabilization is associated with decreased levels of lactic acid in the rumen. Stimulating lactic acid-utilizing bacteria could account for decreases in lactic acid concentrations induced by S. cerevisiae and the corresponding moderation of the rumen $\mathrm{pH}$. The role of yeast is to stimulate lactate users, increase the number of lactate users, and serve as a competitor with lactate producers [8]. Moreover, it is interesting that the addition of LY increased ruminal $\mathrm{pH}(p<0.05)$, and it is in agreement with a previous study by Dias et al. [35], who found that supplementing S. cerevisiae in the diet with high starch increased ruminal $\mathrm{pH}$, whereas the concentration of lactate was reduced in lactating dairy cows. 
Table 3. The effect of roughage-to-concentrate (R:C) ratio with live yeast (LY) supplementation on rumen ecology and in vitro digestibility.

\begin{tabular}{|c|c|c|c|c|c|c|c|c|c|}
\hline \multirow[b]{2}{*}{ Trt } & \multirow[b]{2}{*}{$\mathrm{R}: \mathrm{C}^{1}$} & \multirow[b]{2}{*}{$\mathrm{LY}^{2}$} & \multicolumn{2}{|c|}{$\mathrm{pH}$} & \multirow{2}{*}{$\begin{array}{l}\mathrm{NH}_{3}-\mathrm{N} \\
(\mathrm{mg} / \mathrm{dL})\end{array}$} & \multicolumn{4}{|c|}{ In Vitro Digestibility, \% } \\
\hline & & & $4 \mathrm{~h}$ & $8 \mathrm{~h}$ & & $\begin{array}{l}\text { IVDMD } \\
12 \mathrm{~h}\end{array}$ & $\begin{array}{c}\text { IVDMD } \\
24 \mathrm{~h}\end{array}$ & $\begin{array}{l}\text { IVOMD } \\
12 \mathrm{~h}\end{array}$ & $\begin{array}{c}\text { IVOMD } \\
24 \mathrm{~h}\end{array}$ \\
\hline 1 & $80: 20$ & 0 & 6.72 & 6.52 & 19.1 & 61.0 & 64.6 & 71.6 & 77.4 \\
\hline 2 & & 2 & 6.86 & 6.61 & 18.6 & 63.6 & 67.4 & 72.8 & 78.8 \\
\hline 3 & & 4 & 6.85 & 6.76 & 17.0 & 65.6 & 69.6 & 73.3 & 79.3 \\
\hline 4 & & 6 & 6.88 & 6.81 & 17.2 & 64.2 & 68.0 & 73.0 & 79.0 \\
\hline 5 & $60: 40$ & 0 & 6.54 & 6.49 & 20.5 & 63.2 & 67.0 & 68.8 & 74.4 \\
\hline 6 & & 2 & 6.53 & 6.50 & 19.4 & 64.4 & 68.2 & 70.3 & 76.1 \\
\hline 7 & & 4 & 6.65 & 6.69 & 18.6 & 65.6 & 69.6 & 71.6 & 77.4 \\
\hline 8 & & 6 & 6.62 & 6.71 & 18.5 & 65.4 & 69.4 & 71.2 & 77.0 \\
\hline 9 & $40: 60$ & 0 & 6.41 & 6.15 & 22.9 & 67.6 & 71.6 & 75.1 & 81.1 \\
\hline 10 & & 2 & 6.45 & 6.30 & 22.3 & 76.3 & 80.9 & 78.2 & 84.6 \\
\hline 11 & & 4 & 6.49 & 6.56 & 21.4 & 77.5 & 82.1 & 78.8 & 85.2 \\
\hline 12 & & 6 & 6.50 & 6.58 & 20.9 & 76.5 & 81.1 & 78.3 & 84.7 \\
\hline 13 & $20: 80$ & 0 & 6.42 & 6.20 & 24.1 & 70.9 & 78.1 & 79.2 & 80.6 \\
\hline 14 & & 2 & 6.43 & 6.22 & 24.0 & 72.3 & 86.7 & 82.2 & 88.8 \\
\hline 15 & & 4 & 6.49 & 6.25 & 22.8 & 73.0 & 88.4 & 83.4 & 90.2 \\
\hline \multirow[t]{6}{*}{16} & & 6 & 6.49 & 6.28 & 21.6 & 72.7 & 88.8 & 84.2 & 91.0 \\
\hline & SEM & & 0.38 & 0.57 & 0.77 & 1.97 & 2.43 & 1.85 & 2.47 \\
\hline & Comparison & & & & & & & & \\
\hline & R:C & & 0.02 & 0.02 & 0.04 & 0.009 & 0.02 & 0.03 & 0.009 \\
\hline & LY & & 0.01 & 0.03 & 0.02 & 0.02 & 0.01 & 0.02 & 0.01 \\
\hline & Interaction & & 0.14 & 0.61 & 0.80 & 0.39 & 0.45 & 0.82 & 0.78 \\
\hline
\end{tabular}

1 R:C, roughage-to-concentrate ratio; ${ }^{2} \mathrm{LY}$, live yeast addition $\left(\times 10^{6}\right.$ colony-forming unit); $\mathrm{NH}_{3}-\mathrm{N}$, ammonia-nitrogen $\mathrm{pH} 4, \mathrm{pH}$ at $4 \mathrm{~h}$ after incubation; $\mathrm{pH} 8, \mathrm{pH}$ at $8 \mathrm{~h}$ after incubation; IVDMD $12 \mathrm{~h}$, in vitro dry matter digestibility at $12 \mathrm{~h}$ after incubation; IVDMD24 h, in vitro dry matter digestibility at $24 \mathrm{~h}$ after incubation; IVOMD12 $\mathrm{h}$, in vitro organic matter digestibility at $12 \mathrm{~h}$ after incubation; IVOMD $24 \mathrm{~h}$, in vitro organic matter digestibility at $24 \mathrm{~h}$ after incubation; SEM, standard error of the mean.

Bacteria and protozoa attack dietary protein in the rumen and rapidly degrade it into peptides, amino acids, and $\mathrm{NH}_{3}-\mathrm{N}$. Ammonia is the principal source of nitrogen for microbial protein synthesis, and as the sole source of $\mathrm{N}$, bacteria can grow with $\mathrm{NH}_{3}-\mathrm{N}$. The current study found that the $\mathrm{NH}_{3}-\mathrm{N}$ concentration ranged from 17.1 to $24.1 \mathrm{mg} / \mathrm{dL}$. The $\mathrm{NH}_{3}-\mathrm{N}$ was highest in the $\mathrm{R}: \mathrm{C}$ ratio of 20:80. This could be due to the fact that a higher $\mathrm{CP}$ from high-concentrate diet ration may supply microbial breakdown into high concentrations of $\mathrm{NH}_{3}-\mathrm{N}$ than those with a low ratio concentrate diet [36]. Wanapat and Pimpa [37] suggested that an optimal concentration of $\mathrm{NH}_{3}-\mathrm{N}$, ranging from 15 to $30 \mathrm{mg} / \mathrm{dL}$, may enhance voluntary feed intake, microbial protein synthesis, digestibility of nutrients, and rumen ecology, whereas $\mathrm{NH}_{3}-\mathrm{N}$ deficiency inhibits the growth rate of bacteria. Furthermore, the addition of LY significantly reduced the $\mathrm{NH}_{3}-\mathrm{N}$ concentration $(p<0.05)$, which was similar to the results of Kumprechtova et al. [9], who found that the $\mathrm{NH}_{3}-\mathrm{N}$ concentration in the rumen was numerically lower in dairy cows supplemented with LY addition of S. cerevisiae. These data show that concentration of $\mathrm{NH}_{3}-\mathrm{N}$ may not be the microbial-growth-limiting factor. However, this result can be associated with higher total bacteria populations. The increase in VFA concentrations in this present study indicates enhanced microbial activity in terms of fermentation and agrees with previous findings regarding total bacteria populations [2,4]. The decrease in the ruminal $\mathrm{NH}_{3}-\mathrm{N}$ concentration seemed to be due to increased absorption of $\mathrm{NH}_{3}-\mathrm{N}$ into microbial proteins, probably because of the stimulation of microbial activity by S. cerevisiae $[38,39]$. 
Table 4. The effect of roughage-to-concentrate (R:C) ratio with live yeast (LY) supplementation on in vitro total volatile fatty acids (TVFA), VFA profiles, and methane $\left(\mathrm{CH}_{4}\right)$ production.

\begin{tabular}{|c|c|c|c|c|c|c|c|c|}
\hline Treatment & $\mathrm{R}: \mathrm{C}^{1}$ & $\mathrm{LY}^{2}$ & $\begin{array}{l}\text { Total VFA, } \\
(\mathrm{mM} / \mathrm{l})\end{array}$ & $\begin{array}{l}\mathrm{C} 2, \\
(\%)\end{array}$ & $\begin{array}{l}\text { C3, } \\
(\%)\end{array}$ & $\begin{array}{l}\text { C4, } \\
(\%)\end{array}$ & $\begin{array}{l}\text { C2:C3 } \\
\text { Ratio }\end{array}$ & $\mathrm{CH}_{4}$ Production ${ }^{3}, \mathrm{mM}$ \\
\hline 1 & \multirow[t]{4}{*}{$80: 20$} & 0 & 43.2 & 71.9 & 13.9 & 8.8 & 3.7 & 30.6 \\
\hline 2 & & 2 & 44.1 & 68.1 & 23.8 & 8.1 & 2.9 & 27.3 \\
\hline 3 & & 4 & 43.5 & 66.4 & 25.1 & 8.4 & 2.6 & 26.3 \\
\hline 4 & & 6 & 44.6 & 66.1 & 24.5 & 9.3 & 2.7 & 26.7 \\
\hline 5 & \multirow[t]{4}{*}{$60: 40$} & 0 & 45.2 & 71.4 & 19.7 & 8.9 & 3.6 & 30.3 \\
\hline 6 & & 2 & 47.5 & 65.0 & 25.0 & 10.0 & 2.6 & 26.4 \\
\hline 7 & & 4 & 46.8 & 65.2 & 25.2 & 9.6 & 2.6 & 26.3 \\
\hline 8 & & 6 & 47.1 & 64.9 & 26.6 & 8.5 & 2.4 & 25.3 \\
\hline 9 & \multirow[t]{4}{*}{$40: 60$} & 0 & 43.9 & 70.1 & 22.5 & 7.4 & 3.1 & 28.3 \\
\hline 10 & & 2 & 45.8 & 65.0 & 26.8 & 8.2 & 2.4 & 25.2 \\
\hline 11 & & 4 & 46.3 & 65.8 & 26.4 & 7.8 & 2.5 & 25.5 \\
\hline 12 & & 6 & 47.1 & 61.3 & 27.1 & 11.6 & 2.3 & 24.8 \\
\hline 13 & \multirow[t]{4}{*}{$20: 80$} & 0 & 45.2 & 67.8 & 26.1 & 6.2 & 2.6 & 25.8 \\
\hline 14 & & 2 & 48.1 & 62.9 & 29.7 & 7.4 & 2.1 & 23.1 \\
\hline 15 & & 4 & 48.2 & 59.1 & 30.4 & 10.5 & 1.9 & 22.4 \\
\hline 16 & & 6 & 50.4 & 59.0 & 30.6 & 10.4 & 1.9 & 22.0 \\
\hline \multicolumn{3}{|c|}{ SEM } & 2.04 & 0.75 & 0.04 & 0.32 & 0.08 & 0.13 \\
\hline \multicolumn{3}{|c|}{$\mathrm{R}: \mathrm{C}$} & 0.009 & 0.009 & 0.009 & 0.02 & 0.008 & 0.007 \\
\hline \multicolumn{3}{|c|}{ LY } & 0.04 & 0.03 & 0.03 & 0.76 & 0.04 & 0.04 \\
\hline \multicolumn{3}{|c|}{ Interaction } & 0.52 & 0.19 & 0.31 & 0.55 & 0.34 & 0.37 \\
\hline
\end{tabular}

${ }^{1} \mathrm{R}: \mathrm{C}$, roughage-to-concentrate ratio; ${ }^{2} \mathrm{LY}$, live yeast addition $\left(\times 10^{6}\right.$ colony-forming unit); $\mathrm{C} 2$, acetic acid; $\mathrm{C} 3$, propionic acid; C4, butyric acid; ${ }^{3}$ calculated according to Moss et al. [20], $\mathrm{CH}_{4}$ production $=0.45$ (acetic acid) -0.275 (propionic acid) + 0.4 (butyric acid); SEM, standard error of the mean.

\subsection{Volatile Fatty Acid and Methane Production}

Table 4 shows the TVFA, proportion of acetate, propionate, and butyrate. No interaction effect was observed between the R:C ratio and LY addition on TVFA and VFA profiles. The total concentrations of VFA ranged from 43.2 to $50.4 \mathrm{mM}$ in all treatments and were similar to those observed by Wang et al. [7] and Cagle et al. [3]. Increasing the proportion of a concentrate diet increased TVFA and C3, whereas the $\mathrm{C} 2$ and the $\mathrm{C} 2$-to-C3 ratios decreased $(p<0.05)$. When the degradability of feed increased, the TVFA and proportion of $\mathrm{C} 3$ concentrations increased, whereas the proportion and ratio of $\mathrm{C} 2$ to $\mathrm{C} 4$ and C2 to $\mathrm{C} 3$ decreased, respectively $[3,26,40]$. This could be due to the fact that a concentrate contains a fraction of highly degradable carbohydrates, especially starch. A concentrate diet containing high starch tended to ferment toward C3, in which rumen bacteria fermented the soluble carbohydrate and starch in order to increase TVFA and C2, C3, and C4 in their cells [27].

In the current study, TVFA and C 3 increased with the addition of LY at $6 \times 10^{6} \mathrm{cfu}$, which was greater than the control by $11.5 \%$ and $17.2 \%$, respectively. The $\mathrm{C} 2$ and $\mathrm{C} 2$-to-C3 ratios were lower than the control by $14.0 \%$ and $36.8 \%$, respectively. Bakr et al. [41] found increasing TVFA and C3 concentrations in dairy cows fed with $S$. cerevisiae. The addition of S. cerevisiae also changed the molar proportion of VFA specifically the $\mathrm{C} 3$ concentration in the rumen, leading to an increase in the potential glucogenic for ruminants. In contrast, Mutsvangwa et al. [42] discovered the addition of S. cerevisiae on in vitro gas fermentation and indicated no change in the ratio of $\mathrm{C} 2$ to $\mathrm{C} 3$. This variation could be influenced by diverse yeast strains and the kind of diets used in different experiments.

The ability of LY in the rumen could assist in the growth of lactate-consuming and cellulolytic bacterial populations, sequentially aiding in the stabilization of the rumen and increasing the rumen's capacity to digest fiber [43]. The addition of LY might have enhanced the rumen microbial population, resulting in a better fermentation of carbohydrates into VFAs [3].

No interaction effect was observed between the $\mathrm{R}: \mathrm{C}$ ratio and $\mathrm{LY}$ on the $\mathrm{CH}_{4}$ concentration, as shown in Table 4. The calculated ruminal $\mathrm{CH}_{4}$ production decreased with the increasing proportion of 
concentrates in the diet, particularly the R:C ratio, at 20:80, which were in agreement with the report by Anantasook and Wanapat [26] and Kang et al. [27]. This could be due to the fact that a high proportion of $\mathrm{C} 3$ was caused by a decline in the production of $\mathrm{CH}_{4}$ and that the expected shift of $\mathrm{H}_{2}$ from the $\mathrm{CH}_{4}$ pathway made it available for use as $\mathrm{C} 3$ synthesis, which is nutritionally beneficial for ruminants [1].

In the current study, the $\mathrm{CH}_{4}$ production for $\mathrm{LY}$ addition at $6 \times 10^{6} \mathrm{cfu}$ was lower than the control treatment by $17.2 \%$. Mutsvangwa et al. [42] stated that decreased $\mathrm{CH}_{4}$ production with yeast-containing rations may be due to increased C3 production that requires the use of metabolic hydrogen and thus reduces methanogenesis. LY has recently been suggested to minimize $\mathrm{CH}_{4}$, and the production of $\mathrm{CH}_{4}$ in the rumen has been shown to be decreased by inducing an acetogen to consume more hydrogen for the production of $\mathrm{C} 2[43,44]$. These results agreed with the previous research of Lu et al. [45], who reported that the addition of LY reduced the production of $\mathrm{CH}_{4}$ in growing goats. In contrast, Wang et al. [7] found that adding LY to crop straw increased $\mathrm{CH}_{4}$ and that the elevation of $\mathrm{CH}_{4}$ production could result in increased fiber degradation under in vitro gas production. Elghandour et al. [46] conducted an in vitro experiment and proposed that variations in $\mathrm{CH}_{4}$ production between yeast cultures could be due to their varying protein, fat, fiber, and other material contents.

\subsection{Rumen Microorganism}

Table 5 shows the effect of ratio of R:C and LY addition on rumen microorganisms. There was no interaction between the R:C ratio and LY addition. Increasing the proportion of concentrates in the diet increased the total bacteria and protozoal population. This may be due to the fact that protozoal play a role in starch sequestration, decreasing the starch fermentation rate, and thereby maintaining the optimal ruminal $\mathrm{pH}$ for microbial growth. In addition, microbial bacteria in the rumen have been found to continually increase when a rapid fermentation carbohydrate is supplemented [27,35]. This is in agreement with Cherdthong et al. [33], who stated that the synthesis of ruminal microbial bacteria depends on an adequate supply of carbohydrate as an energy source and $\mathrm{NH}_{3}-\mathrm{N}$ for peptide bond synthesis. Anantasook and Wanapat [26] reported that high-level concentrate diet remarkably increased the rumen's total bacteria.

Moreover, the greatest populations of bacteria, protozoa, and fungi at $8 \mathrm{~h}$ after incubation were found with the addition of LY at $6 \times 10^{6} \mathrm{cfu}$, which were higher than the control by $19.0 \%, 20.7 \%$, and $40.4 \%$, respectively. This shows that $S$. cerevisiae may provide growth factors, such as organic acid or vitamins, which might stimulate the cellulolytic bacterial population. Moreover, S. cerevisiae can improve rumen maturity and stabilize ruminal $\mathrm{pH}$, which provides a better environment for the growth of rumen microbes, particularly bacteria and fungi-degrading cellulose [47]. Moreover, the addition of LY in dairy cows has increased the relative abundance of microorganisms used for cellulolytic, amylolytic, and lactate use [48,49]. 
Table 5. The effect of roughage-to-concentrate (R:C) ratio with live yeast (LY) supplementation on microbial population.

\begin{tabular}{|c|c|c|c|c|c|c|c|c|}
\hline \multirow{2}{*}{ Treatment } & \multirow{2}{*}{$R: C^{1}$} & \multirow{2}{*}{$L^{2}{ }^{2}$} & \multicolumn{2}{|c|}{$\begin{array}{c}\text { Bacteria } \\
\left(\times 10^{10} \text { Cells } / \mathrm{mL}\right)\end{array}$} & \multicolumn{2}{|c|}{$\begin{array}{c}\text { Protozoa } \\
\left(\times 10^{5} \text { Cells } / \mathrm{mL}\right)\end{array}$} & \multicolumn{2}{|c|}{$\begin{array}{c}\text { Fungi } \\
\left(\times 10^{3} \text { Cells } / \mathrm{mL}\right)\end{array}$} \\
\hline & & & $4 \mathrm{~h}$ & $8 \mathrm{~h}$ & $4 \mathrm{~h}$ & $8 \mathrm{~h}$ & $4 \mathrm{~h}$ & $8 \mathrm{~h}$ \\
\hline 1 & \multirow[t]{4}{*}{$80: 20$} & 0 & 9.5 & 8.8 & 4.0 & 4.2 & 1.3 & 1.4 \\
\hline 2 & & 2 & 10.3 & 11.0 & 4.6 & 5.3 & 1.9 & 1.9 \\
\hline 3 & & 4 & 10.9 & 11.3 & 4.5 & 5.7 & 1.8 & 2.1 \\
\hline 4 & & 6 & 10.8 & 12.1 & 4.6 & 5.8 & 1.9 & 2.1 \\
\hline 5 & \multirow[t]{4}{*}{$60: 40$} & 0 & 10.3 & 13.4 & 4.4 & 5.6 & 1.7 & 1.8 \\
\hline 6 & & 2 & 12.1 & 14.7 & 5.3 & 5.9 & 2.0 & 2.2 \\
\hline 7 & & 4 & 14.4 & 17.4 & 6.3 & 6.5 & 2.6 & 2.9 \\
\hline 8 & & 6 & 15.3 & 18.8 & 6.1 & 6.5 & 2.7 & 2.8 \\
\hline 9 & \multirow[t]{4}{*}{$40: 60$} & 0 & 13.7 & 16.1 & 6.0 & 7.0 & 2.3 & 2.6 \\
\hline 10 & & 2 & 15.1 & 17.8 & 6.9 & 7.1 & 2.6 & 4.0 \\
\hline 11 & & 4 & 16.5 & 19.8 & 7.8 & 7.9 & 2.5 & 3.8 \\
\hline 12 & & 6 & 16.9 & 20.9 & 7.7 & 8.0 & 2.8 & 4.2 \\
\hline 13 & \multirow[t]{4}{*}{$20: 80$} & 0 & 17.7 & 19.5 & 7.0 & 8.2 & 2.1 & 4.7 \\
\hline 14 & & 2 & 18.3 & 20.7 & 7.3 & 8.5 & 2.3 & 5.1 \\
\hline 15 & & 4 & 19.2 & 22.1 & 8.6 & 9.0 & 2.6 & 5.6 \\
\hline \multirow[t]{6}{*}{16} & & 6 & 20.3 & 23.2 & 8.8 & 9.9 & 2.9 & 6.6 \\
\hline & SEM & & 0.95 & 0.87 & 0.28 & 0.53 & 0.62 & 0.70 \\
\hline & \multicolumn{8}{|l|}{ Comparison } \\
\hline & $\mathrm{RC}$ & & 0.009 & 0.008 & 0.008 & 0.008 & 0.03 & 0.02 \\
\hline & LY & & 0.008 & 0.008 & 0.009 & 0.009 & 0.18 & 0.32 \\
\hline & Interaction & & 0.11 & 0.14 & 0.39 & 0.65 & 0.29 & 0.44 \\
\hline
\end{tabular}

${ }^{1} \mathrm{R}: \mathrm{C}$, roughage: concentrate ratio; ${ }^{2} \mathrm{LY}$, live yeast addition $\left(\times 10^{6}\right.$ colony-forming unit); SEM, standard error of the mean.

\section{Conclusions and Recommendations}

In conclusion, a high ratio of concentrate and addition of LY at $6.0 \times 10^{6} \mathrm{cfu}$ of the total dietary substrate could improve in vitro gas production kinetics, nutrient digestibility, C3 concentration, and the microbial population, as well as reduce the $\mathrm{CH}_{4}$ production. The addition of $\mathrm{LY}$ improved rumen fermentation and reduced in $\mathrm{CH}_{4}$ production; hence, it has potential for antibiotics substitution and is beneficial to be used for feeding ruminant. However, further in vivo research should be conducted especially in lactating dairy cows and feedlot beef cattle.

Author Contributions: Conceptualization, K.P. and A.C.; formal analysis, K.P. and A.C.; investigation, K.P.; methodology, K.P. and B.P.; writing original draft, K.P.; writing review and editing, K.P., M.W., and A.C. All authors have read and agreed to the published version of the manuscript.

Funding: Post-Doctoral Training Scholarship (PD2563-03), Khon Kaen University and the Increase Production Efficiency and Meat Quality of Native Beef and Buffalo Research Group, Khon Kaen University (KKU).

Acknowledgments: We would like to express our appreciation to the Tropical Feed Resources Research and Development Centre (TROFREC), Khon Kaen University (KKU), and Department of Animal Science, Faculty of Agriculture and Technology, Nakhon Phanom University for providing the research facilities.

Conflicts of Interest: The authors declare that they have no conflict of interest.

\section{References}

1. McAllister, T.A.; Beauchemin, K.A.; Alazzeh, A.Y.; Baah, J.; Teather, R.M.; Stanford, K. Review: The use of direct fed microbials to mitigate pathogens and enhance production in cattle. Can. J. Anim. Sci. 2011, 91, 193-211. [CrossRef]

2. Dawson, K.A.; Newman, K.E.; Boiling, J.A. Effect of microbial supplements containing yeast and lactobacilli on roughage fed ruminal microbial activities. J. Anim. Sci. 1996, 62, 43-48. [CrossRef] [PubMed] 
3. Cagle, C.M.; Batista, L.F.D.; Anderson, R.C.; Fonseca, M.A.; Cravey, M.D.; Julien, C.; Tedeschi, L.O. Evaluation of different inclusion levels of dry live yeast impacts on various rumen parameters and in situ digestibilities of dry matter and neutral detergent fiber in growing and finishing beef cattle. J. Anim. Sci. 2019, 97, 4987-4998. [CrossRef] [PubMed]

4. Lascano, G.J.; Heinrichs, A. Rumen fermentation pattern of dairy heifers fed restricted amounts of low, medium, and high concentrate diets without and with yeast culture. Livest. Sci. 2009, 124, 48-57. [CrossRef]

5. Opsi, F.; Fortina, R.; Tassone, S.; Bodas, R.; Lopez, D. Effects of inactivated and live cells of Saccharomyces cerevisiae on in vitro ruminal fermentation of diets with different forage:concentrate ratio. J. Agric. Sci. 2012, 150, 271-283. [CrossRef]

6. Williams, P.E.; Tait, C.A.; Innes, G.M.; Newbold, C.J. Effects of the inclusion of yeast culture (Saccharomyces cerevisiae plus growth medium) in the diet of dairy cows on milk yield and forage degradation and fermentation patterns in the rumen of steers. J. Anim. Sci. 1991, 69, 3016-3302. [CrossRef]

7. Wang, Z.; He, Z.; Beauchemin, K.A.; Tang, S.; Zhou, C.; Han, X.; Wang, M.; Kang, J.; Odongo, N.E.; Tan, Z. Evaluation of different yeast species for improving in vitro fermentation of cereal straws. Asian-Australas. J. Anim. Sci. 2016, 29, 230-240. [CrossRef]

8. Chaucheras-Durand, F.; Ameilbonne, A.; Auffret, P.; Bernard, M.; Mialon, M.M.; Duniere, L.; Forano, E. Supplementation of live yeast based feed additive in early life promotes rumen microbial colonization and fibrolytic potential in lambs. Sci. Rep. 2019, 9, 19216. [CrossRef]

9. Chung, Y.-H.; Walker, N.D.; McGinn, S.M.; Beauchemin, K.A. Differing effects of 2 active dried yeast (Saccharomyces cerevisiae) strains on ruminal acidosis and methane production in non lactating dairy cows. J. Dairy Sci. 2011, 94, 2431-2439. [CrossRef]

10. Kumprechtova, D.; Illekl, J.; Julien, C.; Homolka, P.; Jancik, F.; Auclair, E. Effect of live yeast (Saccharomyces cerevisiae) supplementation on rumen fermentation and metabolic profile of dairy cows in early lactation. J. Anim. Physiol. Anim. Nutr. 2019, 103, 447-455. [CrossRef]

11. Chaucheyras-Durand, F.; Walker, N.D.; Bach, A. Effects of active dry yeasts on the rumen microbial ecosystem: Past, present and future. Anim. Feed Sci. Technol. 2008, 145, 5-26. [CrossRef]

12. Cagle, C.M.; Fonseca, M.A.; Callaway, T.R.; Runyan, C.A.; Cravey, P.M.; Tedeschi, L.O. Evaluation of the effects of live yeast on rumen parameters and in situ digestibility of dry matter and neutral detergent fiber in beef cattle fed growing and finishing diets. Appl. Anim. Sci. 2020, 36, 36-47. [CrossRef]

13. AOAC. Official Methods of Analysis, 19th ed.; Association of Official Analytical Chemists: Gaithersburg, MD, USA, 2012.

14. Van Soest, P.J.; Robertsonand, J.B.; Lewis, B.A. Methods for dietary fiber neutral detergent fiber, and nonstarch polysaccharides in relation to animal nutrition. J. Dairy Sci. 1991, 74, 3583-3597. [CrossRef]

15. National Research Council-NRC. Nutrient Requirements of Dairy Cattle, 7th ed.; National Academy Press: Washington, DC, USA, 2001.

16. Makkar, H.P.S.; Blummel, M.; Becker, K. In vitro effects and interaction between tannins and saponins and fate of tannins in the rumen. J. Sci. Food Agric. 1995, 69, 481-493. [CrossRef]

17. Blummel, M.; Orskov, E.R. Comparison of in vitro gas production and nylon bag degradability of roughage in predicting feed intake in cattle. Anim. Feed Sci. Technol. 1993, 40, 109-119. [CrossRef]

18. Orskov, E.R.; McDonal, I. The estimation of protein degradability in the rumen from incubation measurements weighted according to rate of passage. J. Agric. Sci. 1979, 92, 499-503. [CrossRef]

19. Galyean, M. Laboratory Procedures in Animal Nutrition Research; New Mexico State University: Las Cruces, NM, USA, 1989.

20. Moss, A.R.; Jouany, J.P.; Newbold, J. Methane production by ruminants: Its contribution to global warming. Ann. Zootech. 2000, 49, 231-253. [CrossRef]

21. Tilley, J.M.A.; Terry, R.A. A two-stage technique for the digestion of forage crops. J. Br. Grassl. Soc. 1963, 18, 104-111. [CrossRef]

22. SAS (Statistical Analysis System). User's Guide: Statistic; Version 9.4th ed.; SAS Inst. Inc.: Cary, NC, USA, 2013.

23. Crichton, N. Information point: Tukey Multiple Comparison test. J. Clin. Nurs. 1999, 8, 299-304.

24. Wanapat, M.; Polyorach, S.; Boonnop, K.; Mapato, C.; Cherdthong, A. Effects of treating rice straw with urea or urea and calcium hydroxide upon intake, digestibility, rumen fermentation and milk yield of dairy cows. Livest. Sci. 2009, 125, 238-243. [CrossRef] 
25. Polyorach, S.; Wanapat, M. Improving quality of rice straw by urea and calcium hydroxide on rumen ecology, microbial protein synthesis in beef cattle. J. Anim. Physiol. Anim. Nutr. 2015, 99, 449-456. [CrossRef]

26. Anantasook, N.; Wanapat, M. Influence of rain tree pod meal supplementation on rice straw based diets using in vitro gas fermentation technique. Asian-Australas. J. Anim. Sci. 2012, 5, 325-334. [CrossRef] [PubMed]

27. Kang, S.; Wanapat, M.; Phesatcha, K.; Norrapoke, T.; Foiklang, S.; Ampapon, T.; Phesatcha, B. Using krabok (Irvingia malayana) seed oil and Flimingia macrophylla leaf meal as a rumen enhancer in an in vitro gas production system. Anim. Prod. Sci. 2017, 57, 327-333. [CrossRef]

28. Tang, S.X.; Tayo, G.O.; Tan, Z.L.; Sun, Z.H.; Shen, L.X.; Zhou, C.S.; Xiao, W.J.; Ren, G.P.; Han, X.F.; Shen, S.B. Effects of yeast culture and fibrolytic enzyme supplementation on in vitro fermentation characteristics of low-quality cereal straws. J. Anim. Sci. 2008, 86, 1164-1172. [CrossRef] [PubMed]

29. Hristov, A.N.; Oh, J.; Firkins, J.L.; Dijkstra, J.; Kebreab, E.; Waghorn, G.; Makkar, H.P.S.; Adesogan, A.T.; Yang, W.; Lee, C.; et al. Special Topics-Mitigation of methane and nitrous oxide emissions from animal operations: I. A review of enteric methane mitigation options. J. Anim. Sci. 2013, 91, 5045-5069. [CrossRef] [PubMed]

30. Monnerat, J.P.; Paulino, P.V.; Detmann, E.; Valadares Filho, S.C.; Valadares, R.D.; Duarte, M.S. Effects of Saccharomyces cerevisiae and monensin on digestion, ruminal parameters, and balance of nitrogenous compounds of beef cattle fed diets with different starch concentrations. Trop. Anim. Health Prod. 2013, 45, 1251-1257. [CrossRef]

31. Patra, A.K. The use of live yeast products as microbial feed additives in ruminant nutrition. Asian J. Anim. Vet. Adv. 2012, 7, 366-375. [CrossRef]

32. Campanile, G.; Zicarellia, F.; Vecchio, D.; Pacelli, C.; Negliaa, G.; Balestrieri, A.; Palo, R.D.; Infascelli, F. Effects of Saccharomyces cerevisiae on in vivo organic matter digestibility and milk yield in buffalo cows. Livest. Sci. 2008, 114, 358-361. [CrossRef]

33. Cherdthong, A.; Wanapat, M.; Kongmun, P.; Pilajan, R.; Khejornsart, P. Rumen fermentation, Microbial protein synthesis and cellulolytic bacterial population of swamp buffaloes as affected by roughage to concentrate ratio. J. Anim. Vet. Adv. 2010, 9, 1667-1675. [CrossRef]

34. Wanapat, M.; Gunun, P.; Anantasook, N.; Kang, S. Changes of rumen pH, fermentation and microbial population as influenced by different ratios of roughage (rice straw) to concentrate in dairy steers. J. Agric. Sci. 2014, 152, 675-685. [CrossRef]

35. Dias, A.L.G.; Freitas, J.A.; Micai, B.; Azevedo, R.A.; Greco, L.F.; Santos, J.E.P. Effect of supplemental yeast culture and dietary starch content on rumen fermentation and digestion in dairy cows. J. Dairy Sci. 2018, 101, 201-221. [CrossRef]

36. Paula, E.M.; Broderick, G.A. Effects of replacing soybean meal with canola meal for lactating dairy cows fed 3 different ratios of alfalfa to corn silage. J. Dairy Sci. 2020, 103, 1463-1471. [CrossRef] [PubMed]

37. Wanapat, M.; Pimpa, O. Effect of ruminal $\mathrm{NH}_{3}-\mathrm{N}$ levels on ruminal fermentation, purine derivatives, digestibility and rice straw intake in swamp buffaloes. Asian-Australas. J. Anim Sci. 1999, 12, 904-907. [CrossRef]

38. Comert, M.; Sayan, Y.; Ozelcam, H.; Baykay, G.Y. Effects of Saccharomyces cerevisiae Supplementation and anhydrous ammonia treatment of wheat straw on in-situ degradability and, rumen fermentation and growth performance of yearling lambs. Asian-Ustralas J. Anim. Sci. 2015, 28, 639-646. [CrossRef] [PubMed]

39. Monteiro, H.F.; Lelis, A.L.J.; Brandao, V.L.N.; Faccenda, A.; Avila, A.S.; Arce-Cordero, J.; Silva, L.G.; Dai, X.; Restelatto, R.; Carvalho, P.; et al. In vitro evaluation of Lactobacillus plantarum as direct-fed microbials in high-producing dairy cows diets. Transl. Anim. Sci. 2020, 4, 214-228. [CrossRef]

40. Pelagalli, A.; Musco, N.; Trotta, N.; Cutrignelli, M.I.; Di Francia, A.; Infascelli, F.; Tudisco, R.; Lombardi, P.; Vastolo, A.; Calabrò, S. Chemical characterisation and in vitro gas production kinetics of eight Faba bean varieties. Animals 2020, 10, 398. [CrossRef]

41. Bakr, H.A.; Hassan, M.S.; Giadinis, N.D.; Panousis, N.; Ostojić Andrić, D.; Abd El-Tawab, M.M.; Bojkovski, J. Effect of Saccharomyces cerevisiae supplementation on health and performance of dairy cows during transition and early lactation period. Biotechnol. Anim. Husb. 2015, 31, 349-364. [CrossRef]

42. Mutsvangwa, T.; Edwards, I.E.; Topps, J.H.; Paterson, G.F.M. The effect of dietary inclusion of yeast culture (Yea-sacc) on patterns of rumen fermentation, food intake and growth of intensively fed bulls. Anim. Prod. 1992, 55, 35-41. [CrossRef]

43. Marden, J.P.; Julien, C.; Monteils, V.; Auclair, E.; Moncoulon, R.; Bayourthe, C. How does live yeast differ from sodium bicarbonate to stabilize ruminal $\mathrm{pH}$ in highyielding dairy cows. J. Dairy. Sci. 2008, 9, 3528-3535. [CrossRef] 
44. Haque, M.N. Dietary manipulation: A sustainable way to mitigate methane emissions from ruminants. J. Anim. Sci. Technol. 2018, 50, 15. [CrossRef]

45. Lu, Q.; Wu, J.; Wang, M.; Zhou, C.; Han, X.; Odongo, E.N.; Tan, Z.; Tang, S. Effects of dietary addition of cellulase and a Saccharomyces cerevisiae fermentation product on nutrient digestibility, rumen fermentation and enteric methane emissions in growing goats. Arch. Anim. Nutr. 2016, 70, 224-238. [CrossRef] [PubMed]

46. Elghandour, M.M.Y.; Krusro, A.; Adegbeye, M.J.; Tan, W.; Abu Hafsa, S.H.; Greiner, R.; Uglogu, E.A.; Anele, U.Y.; Salem, A.Z.M. Dynamic role of single-celled fungi in ruminal microbial ecology and activities. J. Appl. Microbiol. 2019, 128, 950-965. [CrossRef] [PubMed]

47. Ghazanfar, S.; Khalid, N.; Ahmed, I.; Imran, M. Probiotic yeast: Mode of action and its effects on ruminant nutrition. In Yeast_Industrial Applications; IntechOpen: Rijeka, Croatia, 2017; pp. 179-202.

48. Jiang, Y.; Ogunade, I.M.; Qi, S.; Hackmann, T.J.; Staples, C.R.; Adesogan, A.T. Effects of the dose and viability of Saccharomyces cerevisiae. Diversity of ruminal microbes as analyzed by Illumina MiSeq sequencing and quantitative PCR. J. Dairy Sci. 2017, 100, 325-342. [CrossRef] [PubMed]

49. Wanapat, M.; Boonnop, K.; Promkot, C.; Cherdthong, A. Effects of alternative protein sources on rumen microbes and productivity of dairy cows. Maejo Int. J. Sci. Technol. 2011, 5, 13-23.

Publisher's Note: MDPI stays neutral with regard to jurisdictional claims in published maps and institutional affiliations.

(C) 2020 by the authors. Licensee MDPI, Basel, Switzerland. This article is an open access article distributed under the terms and conditions of the Creative Commons Attribution (CC BY) license (http://creativecommons.org/licenses/by/4.0/). 